\title{
THE ROOT CAUSES OF FINANCIAL CRISIS IN ISLAMIC ECONOMIC PERSPECTIVE
}

\author{
Ascarya* \\ Central Banking Education and Studies Department \\ Bank Indonesia \\ Jakarta, Indonesia \\ Email: ascarya@bi.go.id \\ Dudy Iskandar \\ Central Banking Education and Studies Department \\ Bank Indonesia \\ Jakarta, Indonesia
}

\begin{abstract}
The ongoing global financial crisis is just a repeat of financial crises which have occurred one after another since the England crisis in 1825. The crises have subsided in the period under Bretton Woods Agreements (BWA) in 1950-1972, with the implementation of gold standard. The crises have reemerged with the collapse of BWA in 1971, and up to 2011 there are 421 financial crises covering 147 banking crises, 218 currency crises (10 episodes in 2008-2011), and 66 sovereign debt crisis, including 68 twin crises and 8 triplet crises (Laeven and Valencia, 2012). These repeated man-made financial crises happened due to the transgressions of God's laws in financial dealings, especially in the abandonment of main pillars of Islamic financial system, namely prohibition of riba (usury or interest), prohibition of maysir (game of chance or speculation) and prohibition of gharar (excessive uncertainty), in their many forms, as well as due to misbehaviors of economic actors, poor governance and unsustainable fiscal system.

This study will apply Analytic Network Process (ANP) to determine the main root causes of financial crisis from Islamic economic perspective which will be grouped into five clusters, namely: Misbehavior, External Factor, Poor Governance, Unstable Monetary System and Unsustainable Fiscal System. Each cluster will have six relevant elements obtained from literatures and in-depth interviews with several experts.

The ANP results show that the main root causes of financial crisis from Islamic economic perspective are Social Instability (EXTERNAL FACTOR), Speculation (MISBEHAVIOR), Ineffective Fiscal System (UNSUSTAINABLE FISCAL SYSTEM), Hedonism (MISBEHAVIOR), Fractional Reserve Banking System (UNSTABLE MONETARY SYSTEM), Political Instability (EXTERNAL FACTOR), Corruption (POOR GOVERNANCE), Interest Rate (UNSTABLE MONETARY SYSTEM), Fiat Money (UNSTABLE MONETARY SYSTEM), and Wrong Man in the Wrong Place (POOR GOVERNANCE). These main root causes should be removed gradually in order to systematically and gradually improve the stability of financial system so that financial crisis will not reappear again and again in the future.
\end{abstract}

Keywords: Financial crisis, Islamic economic perspective, ANP

\section{INTRODUCTION}

\subsection{Background}

Financial crises have occurred one after another since the demise of gold standard regime in 1915, which finally manifested into the great depression in 1929-1930 (Davies, 1996). The crises have subsided in the period under Bretton Woods Agreements (BWA) in 1950-1972, with strict fixed

\footnotetext{
${ }^{*}$ Corresponding author
} 
exchange rate international monetary arrangements where US Dollar as world currency is pegged to gold (one troy ounce of gold is equal to 35 US Dollar) while other currencies are pegged to US Dollar, with the guarantee that US Dollar is exchangeable to gold in any time. David Felix stated that there is no long period of time, in the past or present which is comparable or closely resemble to the achievement (the high production, high productivity, low unemployment, and just distributive income) of BWA era. The BWA eventually collapsed in 1971, when the US unilaterally terminated the convertibility of US Dollar to gold. The US enjoyed huge seigniorage profits from printing fiat currency without gold back up. Other countries finally followed the US to use fiat money and adopted floating exchange rate. Following the collapse of BWA, financial crises have resurfaced more frequently with wider and deeper impacts. The latest global economic development was global financial crisis since August 2007 initiated by subprime mortgage crisis in the USA, which has made tens of financial institutions in troubles and some of them have gone bankrupt, such as Lehman Brothers and Bear Sterns in the US, as well as Northern Rock Bank in the UK (Lietaer, et al., 2009). This global financial crisis has been called by leading economists as the worst financial crisis since the Great Depression of the 1930s. Recently, this contagious global financial crisis has just caused crises in some European countries, such as Greece, Portugal, and Italia.

Since the collapse of BWA there have already been 431 financial crises comprise of 147 banking crises, 218 currency crises (10 episodes in 2008-2011), and 66 sovereign debt crisis, including 68 twin crises and 8 triplet crises (Laeven and Valencia, 2012), which happened not because of cyclical or managerial failures, but because of structural failures in various countries under very different regulatory systems as well as at different stages of economic development (Lietaer et al., 2009). However, the conventional solutions taken only deal with the symptoms, not the root systemic causes of the crisis.

It seems that they have not learned the lessons yet on how to eradicate and/or control the financial crisis. Even though the crisis has been repeated again and again, none of those countries became economically stronger and more stable. Crisis and financial instability subjects that are so much discussed, but so little understood. Therefore, repeated financial crises and unresolved problems of financial instability have triggered paradigm shifts and posted new challenges on how to stop the crisis and design stable financial system in the future, especially in Indonesia which implementing dual financial system.

\subsection{Objective}

The objective of this study is to determine and examine the root causes of financial crisis from various schools of thought, including conventional and Islamic views to be able to develop stable and crisis proof dual financial system that is directed toward the maximum achievement of just and distributive human wellbeing.

\section{Literature Review}

Financial crisis can be viewed from different school of thoughts. This section will discuss financial crisis from Islamic economic perspective.

\subsection{Financial Crisis in Islamic Economic Perspective}

Under Islamic economic perspective, financial crisis could occur due to natural causes and man-made (or human error) causes. Natural financial crisis could happen due to natural disasters and natural business cycle. Meanwhile, man-made financial crisis could happen when the balance in real and financial sectors and their stakeholders are disrupted due to the transgressions of God's laws in financial dealings, especially in the abandonment of main pillars of financial system, namely prohibition of riba (usury or interest), prohibition of maysir (gambling and game of chance or speculation) and prohibition of gharar (excessive uncertainty), in their many forms. Allah says in $\mathrm{Al}$ Qur' an at surah Thaahaa [20]:124: 
"But whosoever turns away from My Reminder (i.e. neither believes in this Quran nor acts on its orders, etc.) verily, for him is a life of hardship, and We shall raise him up blind on the Day of

Other reminder is mentioned in hadits by Ath-Thabrani and $\mathrm{Al}$ Hakim:

When fornication and usury have been widespread in a community, then they (inhabitants) have allowed Allah's punishment to themselves (Ath-Thabrani and Al Hakim). The abandonment of the prohibition of riba could take the forms of: 1) interest system; 2) fiat money system; 3) fractional reserve banking system; 4) leverage system; 5) derivatives; and 6) credit card system. The abandonment of the prohibition of maysir could take the forms of: 7) speculation in stock trading; 8) speculation in foreign exchange trading; 9) speculation in commodity trading; 10) speculation in real estates; and 11) other speculation in any markets. Meanwhile, the abandonment of the prohibition of gharar could take the forms of: 12) complexity in transactions; 13) complexity in the structure of financial products; 14) securitization; 15) hedging; and 16) insurance products.

Moreover, misbehaviors of economic actors in the markets, such as self-interest, monopoly, hoarding, price control, manipulation, asymmetric information, no distributive justice, unfairness, greed, etc. could also propagate financial crisis. Financial sector is a part of economy that supports real sector so that economic activities (especially in production and trade) can run and excel smoothly without any hindrance.

As many other prohibition in Islam, such as gambling (maysir) and liquor (khamr), usury or riba is prohibited in several stages, in line with the readiness of the society of that era. In the first stage in Makkah, surah Ar-Rum (30:39) says that ribā (interest) will deprive wealth from Allah's blessings, while sadaqah (charity) will raise Allah's blessings manifold. In the second stage in the early Madinah period, it is mentioned in surah An-Nisaa (4:161) that riba is severely condemned (which is in line with rib $\bar{a}$ prohibition in previous scriptures) and those who take riba are threatened with severe punishment from Allah. In the third stage in the second or third year of Hijrah, surah Ali Imran (3:130-133) enjoins Muslims who believe to keep away from $r i b \bar{a}$, if they desire Islamic wellbeing. In the fourth stage close to the completion of Prophet's mission, surah Al-Baqarah (2:275-281) severely

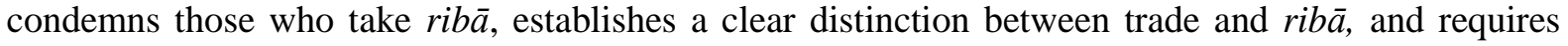
Muslims to annul all outstanding ribāa, instructing them to take only the principal amount, and forego even this in case of the borrowers' hardship (Chapra, 1985). Iqbal and Mirakhor (2011) add that the prohibition of riba $\bar{a}$ is also associated with the notion of injustice. Surah Al-Baqarah (2:279) says “... neither should you commit injustice nor should you be subjected to it".

Maysir is prohibited by Al-Qur'an in several stages. In the first stage, gambling is considered as great sin which also contains some benefit, but the sin is greater than the benefit (Surah Al-Baqarah [2]:219). In the second stage, gambling is described as satan handiwork, so that believers should avoid gambling in order to be successful (Surah Al-Maidah [5]:90). In the last stage, gambling must be stopped and prohibited since it hinders someone from the remembrance of Allah and from the prayer (Surah Al-Maidah [5]:91).

Meanwhile, gharar literally means risk, uncertainty, and hazard (Obaidullah, 2005), so that the concept of gharar broadly defines in two ways, namely: 1) gharar implies uncertainty; and 2) gharar implies deceit. Iqbal and Mirakhor (2011) also define gharar in similar way. Gharar stems from information problems (ignorance or lack of knowledge and asymmetric information), intentionally or unintentionally. In the legal terminology of jurists, Ayub (2007) state that gharar is the sale of a thing which is not present at hand or the sale of a thing whose consequence is not known or a sale involving hazard in which one does not know whether it will come to be or not, e.g. the sale of a fish in water, or a bird in the air. In one hadits, Ibn 'Abbas narrated that Rasulullah SAW prohibited gharar trading or bai' al-gharar (Hadits narrated by Imam ibn Majah, Sunan Ibn Majah vol.3, kitab al-Tijarah, chapter bai' al-gharar, hadits no.2195).

\subsection{Previous Studies}


Studies on current global financial crisis from Islamic economic perspective are many but not as plenty as those of conventional economic perspective. The Task Force on Islamic Finance and Global Financial Stability, organized by Islamic Development Bank - IDB, published a report on Islamic finance and global financial stability (2010), which discusses the resilience of Islamic finance against global financial crisis. There is one special volume of International Journal of Islamic and Middle Eastern Finance and Management, volume 3 number 4 (2010) which comprises of 8 papers. There is a compilation book by Islamic Economic Research Center, King Abdulaziz University - IERC-KAU (2009), which includes 18 papers of prominent Islamic economic and finance scholars. There are also many studies from various journals which discuss financial crisis.

The root causes of financial crisis from Islamic perspective from these studies could be summarized in five groups, namely: 1) misbehaviors of economic actors, including greediness, self-interests, hedonism, speculation, criminal acts and expectation (Almoharby, 2011; Siddiqi, 2009; Mirakhor and Krichene, 2009); 2) external factors and events which are exogenous, including business cycle, natural disaster, contagion, international monetary system, political instability and social instability (Hassan and Kayed, 2009; Oguz and Tabakoglu, 1991); 3) poor governance in public and private institutions, including poor administration, corruption, price control, lack of regulation, lack of disclosure and wrong man in the wrong place (Al-Masri, 2009; Iqbal and Khan, 2004); 4) unstable monetary/financial system, including interest system, fiat money, fractional reserve banking system, leverage system, product derivation and credit creation through credit card (Trabelsi, 2011; Hassan and Kayed, 2009); and 5) unsustainable fiscal system, including unsustainable fiscal deficit, excessive tax, excessive sovereign debt, excessive spending, poor inventory management of strategic commodities and ineffective fiscal system (Chapra, 2007; Iqbal and Khan, 2004).

\section{Methodology}

This study will apply qualitative method Analytic Network Process (ANP) in three steps. First, indepth interviews with scholars and experts of Islamic economic and finance are conducted to fully comprehend the real problems and identify the root causes of financial crisis. Second, the results of the preliminary stage are used to develop an appropriate ANP network and relevant questionnaires to glean the necessary data from seven scholars and experts of Islamic economic and finance. Third, ANP analysis is applied to prioritize key root causes of financial crisis and to set policy strategies in order to formulate optimal policy recommendations.

\subsection{Steps of Research}

Based on ANP methodology, the main steps of ANP modeling are: 1) Decomposition, which is the development of ANP network of the problem; 2) Measurement, which is pairwise comparisons on the elements and relative weight estimation of all dependence and feedback relationships in the ANP network; and 3) Synthesis, which includes construction and calculation of original unweighted supermatrix, weighted supermatrix, and limiting supermatrix (the global priority weights).

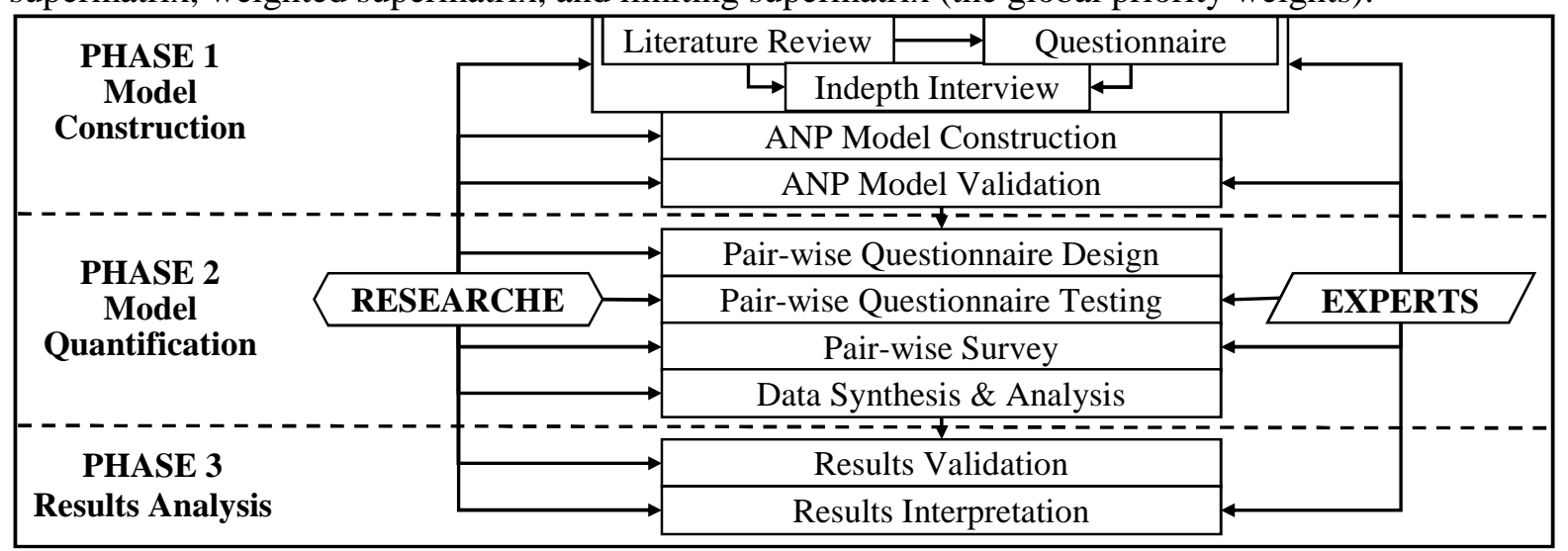

Figure 3.1 Steps of Research

This study comprises of several extended steps of main ANP modeling, which can be grouped into three phases. Phase 1 is model construction or decomposition to identify, analyze and structure the 
complexity of the problems into an appropriate ANP network, which includes: a) Literature reviews, questionnaires and in-depth interviews with experts and practitioners (Islamic bankers) to comprehend the problem fully; b) Construction of ANP network; and c) Validation of ANP network. Phase 2 is model quantification or pair-wise comparison, includes: a) Design pair-wise questionnaires in accordance with ANP network; b) Test the pair-wise questionnaires to respondents (experts and/or Islamic bankers); and c) Survey to respondents to fill out pair-wise questionnaires. Phase 3 is synthesis and results analysis, which includes: a) Data processing and synthesis using ANP software SUPERDECISIONS, as well as results analyses to calculate geometric mean and rater agreement; b) Validation of the results; and c) Interpretations of the results.

\subsection{Conceptual Framework}

The ANP model of this study is structured into several clusters of problems. Problems will include all root causes of financial crisis viewed from Islamic economic perspective, which could be natural causes or man-made (human error) causes. Problems could be divided into five clusters, namely: 1) Misbehavior of economic actors, which transgress Allah's laws; 2) External factors, which could be natural or man-made; 3) Poor governance, especially in government sector; 4) Unstable monetary/financial system, which operates under various riba systems; and 5) Unsustainable fiscal system, which is unjustly designed.

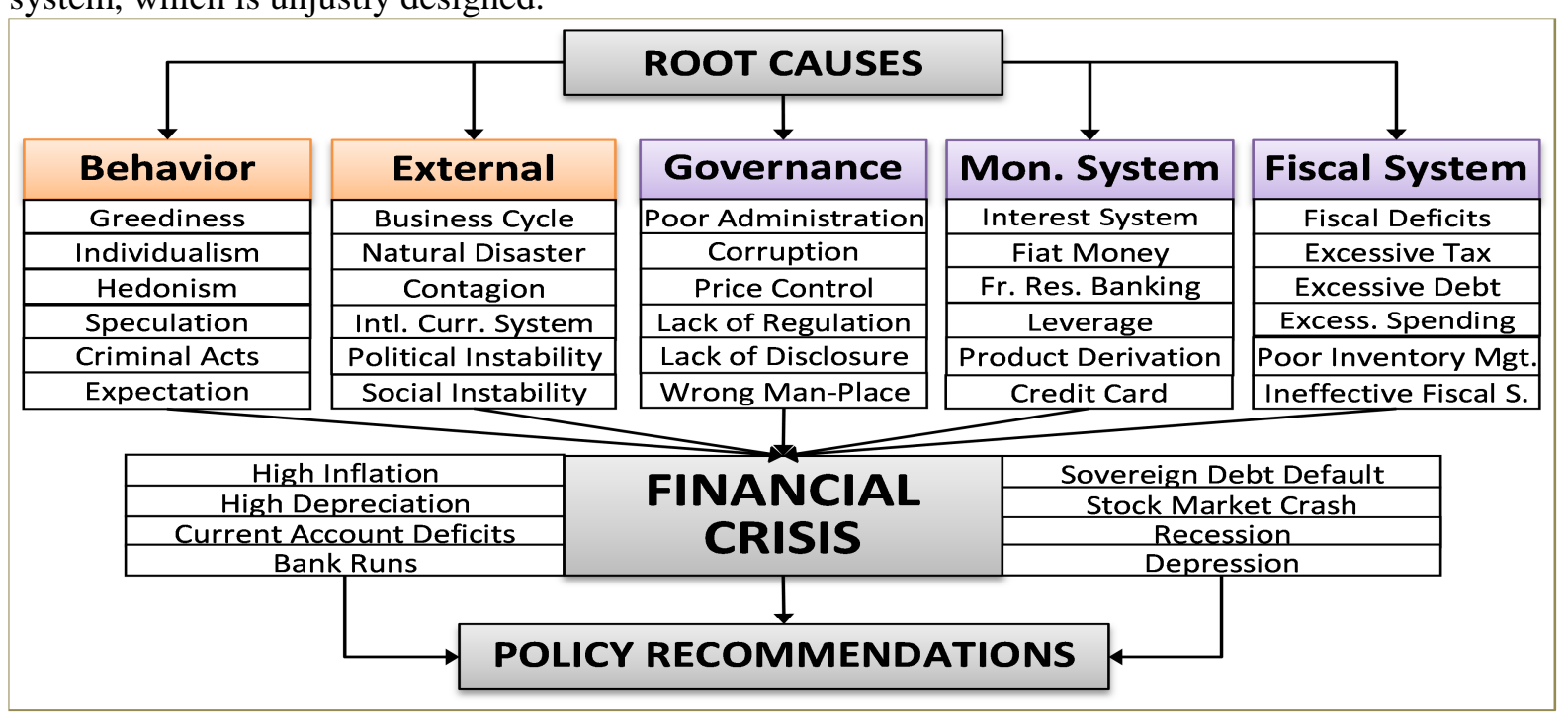

Figure 3.2 The Root Causes of Financial Crisis

Based on the above conceptual framework, the corresponding ANP network for the root causes of financial crisis can be seen in figure 3.3. 


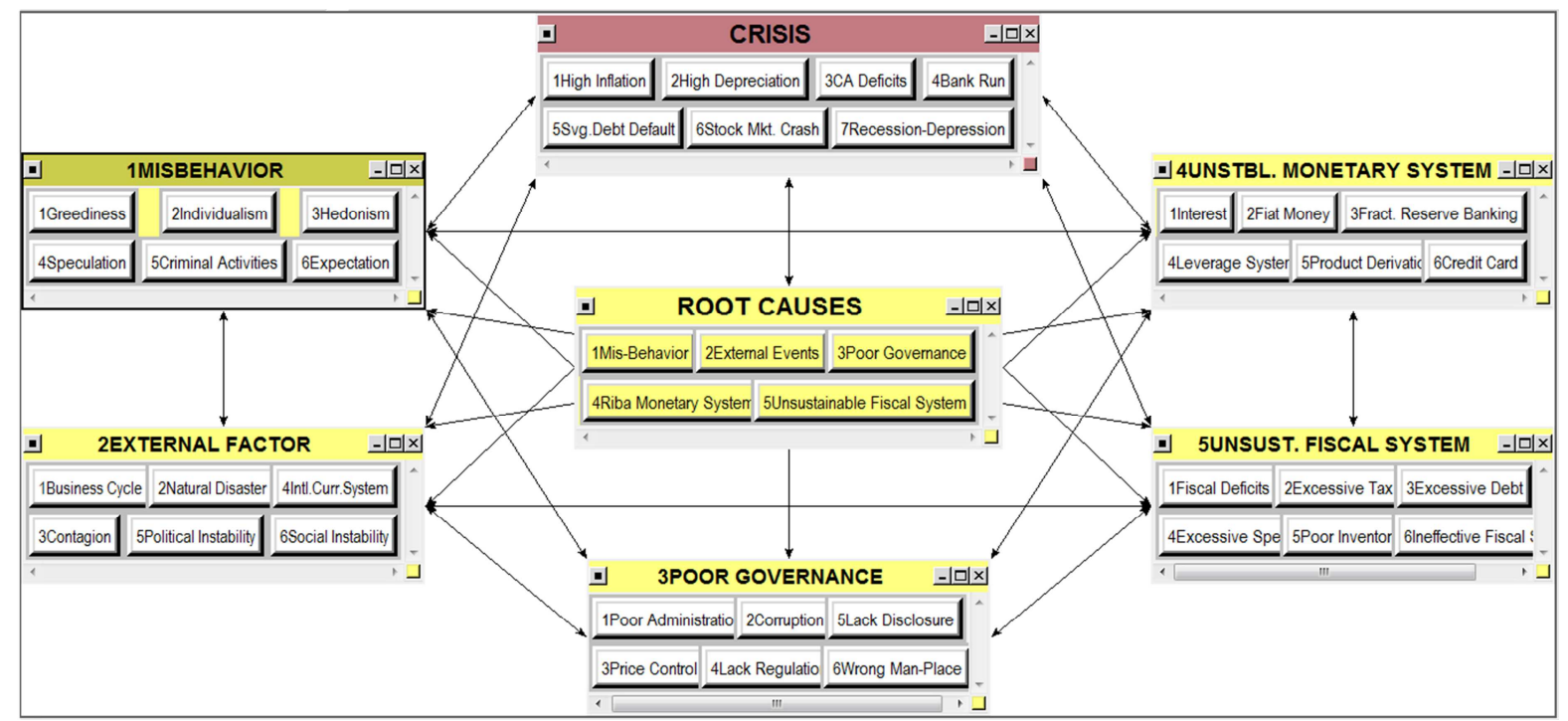

Figure 3.3 ANP Network for The Root Causes of Financial Crisis

\section{Results and Analysis}

Table 4.1 in the appendix shows the summary results of ANP for all clusters, which are shown in two figures, i.e., 'normalized by cluster' and 'limiting'. Value in 'normalized by cluster' column shows relative value of each element to other elements in the cluster, where the total value of all elements in one cluster equals to one. Value in 'limiting' column shows relative values of each element to the entire network, where the total value of all elements in ANP network equals to one.

\section{[Insert Table 4.1]}

The general ANP results show that the main root causes of financial crisis from Islamic economic perspective (see figure 4.1) are Poor Governance (0.243), Unsustainable Fiscal System (0.241) and Unstable Monetary System (0.199). These results are slightly different from those of Ascarya (2013a) using SEM (structural equation modeling), where Unsustainable Fiscal System (loading factor 0.60) is the first main root cause, followed by Poor Governance (loading factor 0.53) and Unstable Monetary System (loading factor 0.51).

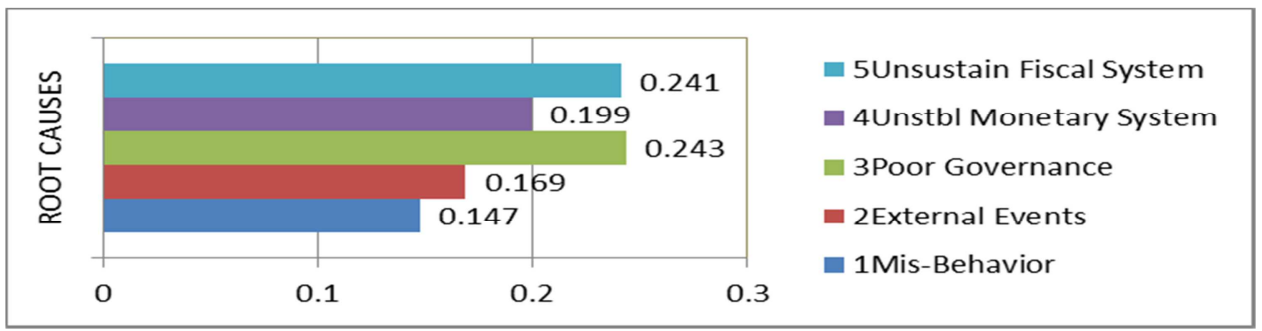

Figure 4.1 General Root Causes of Financial Crisis

The detailed ANP results show that the main root causes of financial crisis from Islamic economic perspective (see figure 4.2) are Social Instability (0.0410), Speculation (0.0402), Ineffective Fiscal System (0.0400), Hedonism (0.0357), Fractional Reserve Banking System (0.0346), Political Instability (0.0318), Corruption (0.03011), Interest Rate (0.301), Fiat Money (0.301), and Wrong Man in the Wrong Place (0.029). In summary, root causes of financial crisis which stand out are Corruption and Wrong Man in the Wrong Place (POOR GOVERNANCE), Ineffective Fiscal System (UNSUSTAINABLE FISCAL SYSTEM), Fractional Reserve Banking System, Interest and Fiat Money (UNSTABLE MONETARY SYSTEM), Social Instability and Political Instability (EXTERNAL FACTOR) and Speculation and Hedonism (MISBEHAVIOR). 


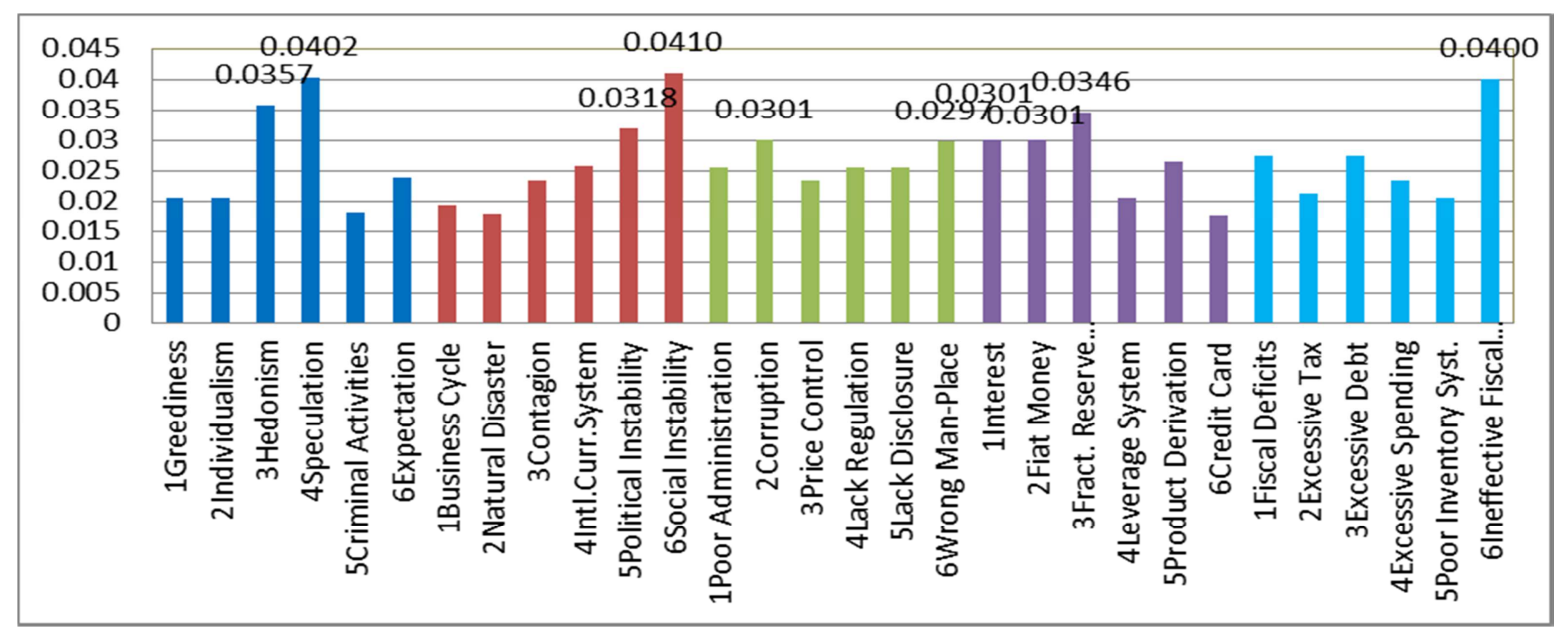

Figure 4.2 Detailed Root Causes of Financial Crisis

POOR GOVERNANCE, especially Corruption and Wrong Man in the Wrong Place, has become the main root causes of financial crisis. corruption is prohibited in Islam, which is stated in several surah in Al-Qur'an, such as surah Al-Maidah [5]:38, surah An-Nisaa [4]:29, surah Ali Imraan [3]:161. Corruption is mentioned in Al-Qur' an surah Huud [11]:85 as follows. "And O my people! Give full measure and weight in justice and reduce not the things that are due to the people, and do not commit mischief in the land, causing corruption." Corruption prohibition is also recorded in several Hadits. For example, hadits narrated by Al-Baihaqi (no.18582), Imam Malik (no.866) and Ibnu Majah (no.2840) as follows. "Hand over even the needle and thread, for stealing from the spoils is disgrace, fire, and ignominy on the Day of Rising for people who do it". Meanwhile, one management rule in Islam is to place the right man in the right position. For example, It is mentioned in one hadits narrated by Imam Muslim in Al-Nawawi's Riyad-us-Saliheen chapter 81, about one companion who ask Rasulullah SAW for a position as government official, as follows. Abu Dharr (May Allah be pleased with him) reported: Messenger of Allah (sallallaahu 'alayhi wa sallam) said to me, "O Abu Dharr, I see that you are weak and I like for you what I like for myself. Do not rule over (even) two persons, and do not manage an orphan's property." Abu Dharr was not the right man for the position he asked, so that Rasulullah SAW refused his request.

UNSUTAINABLE FISCAL SYSTEM, especially Ineffective Fiscal System, has become the main root causes of financial crisis. Al-Qur'an has mentioned in several verses, such as surah Al-Israa' [17]:29 about balanced budget, surah Huud [11]:85 about excessive tax, surah An-Nisaa [4]:9 about excessive government debt for the next generation, surah Al-Furqaan [25]:67 about excessive government spending, surah Al-An'am [6]:141 about not to waste by extravagance and surah AlIsraa' [17]:26-27 about not to spend wealth wastefully. There are also some hadits on fiscal system. Hadits narrated by Ahmad (no.16976) mentions about excessive tax, as follows. "One who wrongfully takes an extra tax (sahib maks) will not enter Paradise.” Hadits narrated by Al-Baihaqi (no.11027) talks about excessive debt. Hadits narrated by Imam Bukhari (no.1272) discuses about leaving surplus wealth for the next generation is better than otherwise. Hadits narrated by Al-Baihaqi (no.6161) talks about living managed budget with chastity is better than riches with extravagance.

UNSTABLE MONETARY SYSTEM, especially Fractional Reserve Banking System, Interest Rate and Fiat Money, has become the main root causes of financial crisis. These three elements are the main pillars of conventional financial system which contain riba (usury) and are prohibited in Islamic economic perspective. Riba is prohibited in several stages, in line with the readiness of the society of that era. In the first stage in Makkah, surah Ar-Rum (30:39) says that riba (interest) will deprive wealth from Allah's blessings, while sadaqah (charity) will raise Allah's blessings manifold. In the second stage in the early Madinah period, it is mentioned in surah An-Nisaa (4:161) that riba is severely condemned (which is in line with riba prohibition in previous scriptures) and those who take rib $\bar{a}$ are threatened with severe punishment from Allah. In the third stage in the second or third year of Hijrah, surah Ali Imran (3:130-133) enjoins Muslims who believe to keep away from riba , if they 
desire Islamic wellbeing. In the fourth stage close to the completion of Prophet's mission, surah AlBaqarah (2:275-281) severely condemns those who take ribā, establishes a clear distinction between

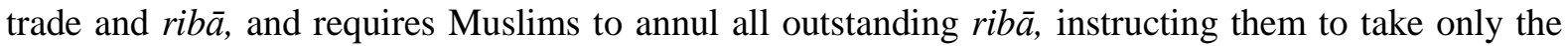
principal amount, and forego even this in case of the borrowers' hardship (Chapra, 1985).

EXTERNAL FACTOR, especially Social Instability and Political Instability are exogenous variables which become the main root causes of financial crisis where the government and regulator do not have control over them. People who make instability in the society are warned in Al-Qur' an surah AlMaidah [5]:33 as follows. "The recompense of those who wage war against Allah and His Messenger and do mischief in the land is only that they shall be killed or crucified or their hands and their feet be cut off on the opposite sides, or be exiled from the land. That is their disgrace in this world, and a great torment is theirs in the Hereafter." It is also narrated in some hadits, such as hadits narrated by Imam Muslim as follows. "Whoever comes to you when you are in one union (of a country) and wants to undermine your solidarity (wants to divide the unity/community), you should fight him (or them)."

MISBEHAVIOR of economic actors, especially Speculation and Hedonism has become the main root causes of financial crisis. Speculation or gambling or Maysir is prohibited in Islam in several stages. In the first stage, gambling is considered as great sin which also contains some benefit, but the sin is greater than the benefit (Surah Al-Baqarah [2]:219). In the second stage, gambling is described as satan handiwork, so that believers should avoid gambling in order to be successful (Surah Al-Maidah [5]:90). In the last stage, gambling must be stopped and prohibited since it hinders someone from the remembrance of Allah and from the prayer (Surah Al-Maidah [5]:91). Meanwhile, Hedonic way of live is warned by Al-Qur'an in Surah At-Takaatsur [102]:1-8. Allah warns that people who piling up worldly things will have diverted live and will be questioned in the Day of judgment (they indulged in, in this world), and finally will be punished.

\section{Conclusion and Recommendation}

\subsection{Conclusion}

Financial crises have occurred one after another with greater frequency and intensity affecting wider region which happened not just because of cyclical or managerial failures, but mostly because of structural failures in various countries under very different regulatory systems as well as at different stages of economic development.

Viewed from Islamic economic perspective, the root causes of financial crisis are the transgressions of Allah's laws of financial dealings in many forms, such as MISBEHAVIOR of economic actors in financial and real markets, POOR GOVERNANCE in public and private institutions, UNSTABLE MONETARY SYSTEM based on usurious conducts, and UNSUSTAINABLE FISCAL SYSTEM which contains unjust, unfair and exploitative policies. Another root cause of financial crisis is EXTERNAL FACTORS which could be of natural events (such as business cycle and natural disaster) and of man-made events (such as international currency system, political instability and social instability).

The general ANP results show that the main root causes of financial crisis are POOR GOVERNANCE (especially, Corruption and Wrong Man in the Wrong Place), UNSUSTAINABLE FISCAL SYSTEM (especially, Ineffective Fiscal System), UNSTABLE MONETARY SYSTEM (especially, Fractional Reserve Banking System, Interest Rate and Fiat Money), EXTERNAL FACTOR (especially Social Instability and Political Instability), and MISBEHAVIOR of economic actors (especially, Speculation and Hedonism).

The detailed ANP results show that the main root causes of financial crisis from Islamic economic perspective are Social Instability-0.0410 (EXTERNAL FACTOR), Speculation-0.0402 (MISBEHAVIOR), Ineffective Fiscal System-0.0400 (UNSUSTAINABLE FISCAL SYSTEM), Hedonism-0.0357 (MISBEHAVIOR), Fractional Reserve Banking System-0.0346 (UNSTABLE 
MONETARY SYSTEM), Political Instability-0.0318 (EXTERNAL FACTOR), Corruption-0.03011 (POOR GOVERNANCE), Interest Rate-0.301 (UNSTABLE MONETARY SYSTEM), Fiat Money0.301 (UNSTABLE MONETARY SYSTEM), and Wrong Man in the Wrong Place-0.029 (POOR GOVERNANCE).

All of the above mentioned root causes of financial crisis have been warned and/or prohibited in Islam, which have been stated in the Holy Book Al-Qur'an and/or Hadits (the sayings) of the prophet (Rasulullah) Muhammad, Salallahu Alaihi Wasallam. Every deviation and transgression of Allah's laws in financial dealings will lead to financial crisis, directly or indirectly, in the short run or in the long run.

\subsection{Recommendation}

Financial crisis would not happen under Islamic economic system if all Allah's laws in financial dealings were followed. Financial crisis in conventional economic system could be prevented or lessened by gradually adopting Islamic economic and finance laws and regulations, partly or fully, especially the main pillars of Islamic financial system, namely the prohibition of riba (usury or interest), prohibition of maysir (gambling and game of chance or speculation) and prohibition of gharar (excessive uncertainty), in their many forms.

The first controlled main root cause of financial crisis is Speculation or maysir (next to uncontrolled Social Instability), so that the prohibition of speculation in all markets, especially in financial markets should become the first priority. At the end, all of these root causes should be removed gradually in order to systematically and gradually improve the stability of financial system so that financial crisis will not reappear again and again in the future.

\section{REFERENCES}

Al-Masri, R.Y. (2009) The Global Financial Crisis: Its Causes and Solutions from an Islamic Perspective. In: Islamic Economic Research Center. Issues in the International Financial Crisis from an Islamic Perspective. Jeddah, KSA: Scientific Publishing Center King Abdulaziz University, pp 287-295.

Almoharby, D. (2011). The Current World Business Meltdown: Islamic Religion as a Regulator. Humanomics, 27(2), pp.97-108.

Ayub, M. (2007). Understanding Islamic Finance. London, United Kingdom: John Willey \& Sons.

Chapra, M.U. (1985). Towards a Just Monetary System. United Kingdom: The Islamic Foundation.

Chapra, M.U. (2007). The Case Against Interest: Is It Compelling? Thunderbird International Business Review, 49(2), pp.161-186.

Davies, G. (1996). A History of Money from Ancient Times to the Present Day. Cardiff, United Kingdom: University of Wales Press.

Hassan, M.K. and Kayed, R.N. (2009). The Global Financial Crisis, Risk Management and Social Justice in Islamic Finance. ISRA International Journal of Islamic Finance, 1(1), pp.33-58.

Iqbal, M. and Khan, T. (2004). Financing Public Expenditure: An Islamic Perspective. Occasional Paper, 7. Jeddah: Islamic Development Bank Islamic Research and Training Institute.

Iqbal, Z. and Mirakhor, A. (2011). An Introduction to Islamic Finance: Theory and Finance Second Edition, Singapore: John Willey \& Sons (Asia). 
Laeven, L. and Valencia, F. (2012). Systemic Banking Crises Database: An Update. IMF Working Paper, WP/12/163.

Lietaer, B., Ulanowicz, R. and Goerner, S. (2009). Options for Managing a Systemic Bank Crisis. S.A.P.I.EN.S, 2(1).

Mirakhor, A. and Krichene, N. (2009). Recent Crisis: Lessons for Islamic Fiance. Journal of Islamic Economics, Banking and Finance, 5(1), pp.9-57.

Obaidullah, M. (2005). Islamic Financial Services. Jeddah, KSA: Islamic Economics Research Center, King Abdulaziz University.

Oguz, O. and Tabakoglu, A. (1991). An Historical Approach to Islamic Pricing Policy: A Research on the Ottoman Price System and its Application. Journal of King Abdulaziz University: Islamic Economics, 3, pp.63-79.

Siddiqi, M.N. (2009) Current Financial Crisis and islamic Economics. In: Islamic Economic Research Center. Issues in the International Financial Crisis from an Islamic Perspective. Jeddah, KSA: Scientific Publishing Center King Abdulaziz University, pp 1-10.

Trabelsi, M.A. (2011). The Impact of the Financial Crisis on the Global Economy: Can the Islamic Financial System Help? The Journal of Risk Finance, 12(1), pp.15-25. Emerald Group Publishing Limited.

\section{APPENDIX 1: Table 4.1 ANP RESULTS}

\begin{tabular}{|c|c|c|c|c|c|}
\hline Name & Limiting & \begin{tabular}{|l|} 
Normalized \\
By Cluster
\end{tabular} & Name & Limiting & \begin{tabular}{|l|} 
Normalized \\
By Cluster
\end{tabular} \\
\hline \multicolumn{6}{|l|}{ CRISIS } \\
\hline High Inflation & 0.018708 & 0.10757 & Saving Debt Default & 0.020557 & 0.1182 \\
\hline High Depreciation & 0.029688 & 0.17071 & Stock Market Crash & 0.022523 & 0.12951 \\
\hline C. Account Deficits & 0.020557 & 0.1182 & Recession-Depression & 0.041939 & 0.24115 \\
\hline Bank Run & 0.019941 & 0.11466 & & & \\
\hline \multicolumn{6}{|l|}{ ROOT CAUSES } \\
\hline Mis-Behavior & 0.004272 & 0.14739 & Unstable Monetary Syst. & 0.005782 & 0.19948 \\
\hline External Event & 0.004887 & 0.1686 & Unsustainable Fiscal Syst. & 0.00699 & 0.24116 \\
\hline Poor Governance & 0.007054 & 0.24337 & & & \\
\hline \multicolumn{3}{|l|}{ MIS-BEHAVIOR } & \multicolumn{3}{|c|}{ UNSTABLE MONETARY SYSTEM } \\
\hline Greediness & 0.020501 & 0.12911 & Interest & 0.030097 & 0.1888 \\
\hline Individualism & 0.020501 & 0.12911 & Fiat Money & 0.030097 & 0.1888 \\
\hline Hedonism & 0.035694 & 0.22479 & Fract. Reserve Banking & 0.034634 & 0.21726 \\
\hline Speculation & 0.040212 & 0.25325 & Leverage System & 0.020465 & 0.12838 \\
\hline Criminal Activities & 0.018156 & 0.11434 & Product Derivation & 0.026563 & 0.16663 \\
\hline Expectation & 0.023721 & 0.14939 & Credit Card & 0.017558 & 0.11014 \\
\hline \multicolumn{3}{|c|}{ EXTERNAL EVENT } & \multicolumn{3}{|c|}{ UNSUSTAINABLE FISCAL SYSTEM } \\
\hline Business Cycle & 0.019414 & 0.12207 & Fiscal Deficits & 0.027389 & 0.17127 \\
\hline Natural Disaster & 0.017788 & 0.11185 & Excessive Tax & 0.021259 & 0.13294 \\
\hline Contagion & 0.023332 & 0.1467 & Excessive Debt & 0.02736 & 0.17109 \\
\hline Intl. Curr. System & 0.025696 & 0.16157 & Excessive Spending & 0.02339 & 0.14626 \\
\hline
\end{tabular}




\begin{tabular}{|l|c|c|c|c|c|} 
Political Instability & 0.031836 & 0.20017 & Poor Inventory Syst. & 0.020499 & 0.12819 \\
\hline Social Instability & 0.040975 & 0.25764 & Ineffective Fiscal Syst. & 0.04002 & 0.25025 \\
\hline \multicolumn{2}{|l|}{ POOR GOVERNANCE } & & & \\
\hline Poor Administr. & 0.025606 & 0.1601 & & \\
\hline Corruption & 0.030106 & 0.18823 & & \\
\hline Price Control & 0.023271 & 0.1455 & & \\
\hline Lack of Regulation & 0.025606 & 0.1601 & \\
\hline Lack of Disclosure & 0.025606 & 0.1601 & \\
\hline Wrong Man-Place & 0.029747 & 0.18599 \\
\end{tabular}

